Jurnal Ilmu Dan Teknologi Kesehatan

Vol 6, No 1, September 2018,

ISSN: 2338-9095 (Print)

ISSN: 2338-9109 (online)

\title{
Trunk Balance Exercise dan Strength Training Exercise Menurunkan Nyeri Punggung Bawah Pasca 12-18 Bulan Pasca Salin
}

\author{
Andriani Khairunnisa ${ }^{1}$, Roikhatul Jannah ${ }^{2}$ \\ Yayasan Pendidikan Anak Istimewa (YPAI) Indriya Bogor \\ andriannis86@gmail.com
}

\begin{abstract}
Artikel history
Dikirim, Jun $20^{\text {th }}, 2018$

Ditinjau, Aug $20^{\text {th }}, 2018$

Diterima, Aug $27^{\text {th }}, 2018$
\end{abstract}

\section{ABSTRACT}

Postpartum is a condition at the time of period after delivery from 0 (zero) to sixth weeks, indicated by various musculoskeletal complaints including lower back pain. This pain is related to postural changes after pregnancy, muscle fatigue, and other physiological changes postpartum. Trunk Balance Exercise and Strength Training Exercise are two exercises combined from various references to overcome low back pain consisting of the exercise of postural muscle balance and strengthening of the spinal segment muscles. The purpose of this study was to determine the effect of the combination exercise on lower back pain related to functional ability among the mother 12-18 after delivery. This study uses a pre-experimental design with one group pretest-posttest approach. The intervention was 12 time of 45-60 minutes meeting session during 4 weeks. Respondents were selected by purposive sampling technique. A total of 15 women post 12-18 months of delivery in Posyandu in Cipayung District, East Jakarta participated in this study. The results were obtained by analyzing univariate and bivariate data; normality test data by dividing the value skewness and standard error; and test hypotheses with Paired t-test. This research shows a significant decrease in the Numerical Rating Scale (NRS) with $p=0.00<0.05$. Conclusion: Trunk Balance Exercise and Strength Training Exercise have an effect against low back pain associated with functional ability in post-12-18 mothers.

Keywords: Lower Back Pain, Postpartum, Trunk Balance Exercise, Strength Training Exercise

\begin{abstract}
ABSTRAK
Postpartum merupakan kondisi pasca persalinan dari 0 (nol sampai enam minggu yang sering ditunjukkan dengan berbagai keluhan musculoskeletal termasuk nyeri pinggang bawah. Nyeri ini berkaitan dengan perubahan postural setelah kehamilan, kelelahan otot, dan perubahan fisiologis lain pascapersalinan. Trunk Balance Exercise dan Strength Training Exercise adalah dua latihan yang digabungkan dari berbagai referensi untuk mengatasi nyeri punggung bawah terdiri dari latihan keseimbangan otot postural dan penguatan otot segmen spinal. Tujuan dari penelitian ini untuk mengetahui pengaruh Trunk Balance Exercise dan Strength Training Exercise terhadap nyeri punggung bawah yang berkaitan dengan kemampuan fungsional pada
\end{abstract}


Ibu pasca 12-18 persalinan. Penelitian ini menggunakan metode pre eksperimental dengan pendekatan one group pretest-posttest dilakukan selama 4 minggu, sebanyak 12 sesi pertemuan, dengan durasi 45-60 menit pada setiap pertemuan. Responden dipilih dengan teknik purposive sampling. Sebanyak 15 wanita pasca 12-18 bulan persalinan di Posyandu Wilayah Kelurahan Cipayung Jakarta Timur berpartisipasi pada penelitian ini. Hasil penelitian didapatkan dengan analisis data univariat dan bivariate; uji normalitas data dengan membagi nilai skewness dan standar errornya; dan uji hipotesis dengan Paired T Test. Penelitian ini menunjukkan penurunan Numerical Rating Scale (NRS) secara bermakna dengan $\mathrm{p}=0,00<0,05$. Simpulan: Trunk Balance Exercise dan Strength Training Exercise berpengaruh terhadap nyeri punggung bawah yang berkaitan dengan kemampuan fungsional pada Ibu pasca 12-18 persalinan.

Kata Kunci: Nyeri Punggung Bawah, Pascapersalinan, Trunk Balance Exercise, Strength Training Exercise

\section{PENDAHULUAN}

Pascapersalinan adalah masa dimana seorang ibu telah mampu melalui proses persalinan terhitung sejak 1 jam setelah lahirnya janin. Masa nifas yang terhitung dari 1 jam hingga 6 minggu setelah persalinan dan periode pasca persalinan pada masa setelahnya menjadi proses panjang bagi wanita yang kemudian akan dikaitkan dengan adanya perubahan bentuk serta fungsi tubuh (Lilis 2013).

Periode pascapersalinan ditandai dengan perubahan yang dramatis dan membutuhkan penyesuaian, dan membuat wanita lebih rentan terhadap efek stres pascapersalinan dan kesehatan fisik mereka (Bastiaenen dan D 2008). Setelah proses persalinan, wanita akan mengalami rasa sakit dan perasaan lelah akibat perubahan fisiologis yang luar biasa mereka alami selama proses persalinan berlangsung. Kekhawatiran wanita terhadap perubahan tubuh selama periode pascapersalinan awal berhubungan dengan luka jahitan pada perineum, perawatan payudara, estetika tubuh dan kelelahan (Bahadoran 2007).

Permasalahan musculoskeletal yang dapat terjadi pada pascapersalinan diantaranya pelvic floor dysfunction, diastasis recti, pelvic asymmetry \& trauma pada cocyxy yang menimbulkan gejala berupa pelvic girdle pain (PGP), thoracic outlet syndrome, patologi pada kaki, dan sindrom postural, dan nyeri punggung (Irion dan Irion 2010).

Nyeri punggung bawah pada pasca persalinan adalah sensasi nyeri pada area punggungb bawah yang dapat diakibatkan oleh perubahan postural selama kehamilan dimana terjadi peningkatan nyeri akibat kelelahan otot yang diakibatkan perubahan fisiologis dari adanya janin, dan dapat 
berkelanjutan hingga proses persalinan telah berlangsung.

Angka kejadian nyeri punggung pada sebuah studi di yang dilakukan di London tahun 1992, dari 817 wanita ditemukan 67\% dari wanita tersebut mengalami nyeri punggung pascapersalinan dan $37 \%$ diantara wanita tersebut mengalami nyeri punggung hingga usia 18 bulan setelah persalinan (Anderson dan O 1992). Sedangkan nyeri punggung bawah dan Pelvic Girdle Pain (PGP) memiliki angka kejadian 20-90\% pada wanita hamil. (Bastiaenen dan D 2008). Namun pada faktanya hingga $75 \%$ wanita yang mengalami kehamilan akan mengalami rasa nyeri kembali setelah persalinan. Sebagian kasus akan menghilang dalam enam bulan pascapersalinan, $40 \%$ mungkin terus mengalami rasa sakit lebih dari enam bulan persalinan. Wanita dengan riwayat nyeri punggung bawah pada masa kehamilan akan menurun keluhannya pada pascapersalinan. Namun, wanita yang mengalami nyeri punggung bawah dan PGP lebih pada tiga bulan pascapersalinan akan beresiko tinggi akan mengalami nyeri punggung bawah kronik hanya sekitar $6 \%$ dapat berkurang dalam waktu 6-18 bulan pascapersalinan (Morgen 2008).
Beberapa kondisi yang beresiko untuk menyebabkan terjadinya nyeri punggung bawah pada pascapersalinan yaitu antara lain riwayat nyeri punggung bawah masa kehamilan yang berlanjut hingga periode pascapersalinan. Adanya riwayat tersebut disebabkan adanya beberapa perubahan sejak masa kehamilan pada aspek mekanik, sirkulasi, fisiologis, dan psikologi serta bentuk tubuh, peningkatan berat badan ibu, peningkatan BMI, perubahan bentuk pelvic, assymatric lumbar akibat keberadaan janin dapat menimbulkan sensasi nyeri punggung bawah.

Usia kehamilan ibu juga dapat menjadi faktor resiko dari nyeri punggung bawah kehamilan hingga postpartum akibat dari terdapatnya penurun fungsi tubuh menjelang dengan usia yang semakin menua. Penurunan fungsi otot abdominal dan back muscle atau paraspinal pascapersalinan membutuhkan waktu yang lebih lama dan mengalami pengenduran sehingga menjadi lemah dan stabilitas terganggu. Hal ini memicu nyeri punggung bawah pascapersalinan.

Permasalahan selama proses persalinan dan peningkatan berat badan pascapersalinan sejak masa kehamilan dapat jadi pemicu dari timbulnya nyeri punggung bawah. Permasalahan tersebut diantaranya adanya 
kegawat daruratan pada proses persalinan, kemudian adanya proses pembedahan pada persalinan, serta adanya komplikasi lain (Jill 2004). Peningkatan berat badan akan menimbulkan penurunan kordinasi antar otot penyangga tubuh karena dapat mengakibatkan pengenduran otot sehingga menjurunkan stabilitas postural pada individu yang mengarahkan pada keluhan nyeri punggung bawah setelah proses persalinan berlangsung (P 2011).

Penanganan postpartum yang kurang tepat seperti tidak melakukan senam nifas pada periode pascapersalinan dapat memperlambat pemulihan otot khususnya abdominal dan back. Kondisi seperti ini dapat menimbulkan nyeri punggung bawah lebih beresiko tinggi dibandingkan dengan individu yangmelakukan penanganan tepat pascapersalinan (Irion dan Irion 2010).

Pada masa kehamilan perawatan fisik menjadi hal penting yang harus wanita utamakan selain untuk kesehatan janin juga berpengaruh terhadap ibu hingga pascapersalinan. Perwatan pada masa kehamilan diantaranya selain menjaga pola hidup juga melakukan olahraga seperti senam hamil. Pengaruh dari dilakukannya olahraga sendiri selain untuk mengurangi permasalahan muskuloskeletal, sirkulasi, dan juga persiapan proses persalinan juga untuk mengurangi permasalahan yang akan timbul pascapersalinan. Permasalahan yang timbul diantaranya Pelvic Girdle Pain (PGP), Diastasis Recti, serta nyeri punggung bawah (Irion dan Irion 2010).

Kemampuan fungsional dapat berkaitan dengan keluhan nyeri punggung bawah. Keluhan ini secara langsung dapat membatasi aktifitas fungsional dan kualitas hidup individu. Hal ini dikarenakan pada nyeri punggung bawah diakibatkan oleh kehamilan yang dapat terjadi hingga pascapersalinan sampai 18 bulan. Nyeri punggung bawah ini memiliki berbagai tipe dari nyeri pada area yang cenderung meluas sesuai dengan lama terkenanya yang kemudian secara klinisi dapat menjadi tanda dan gejala utama atau penyakit yang menyebabkan keterbatan kualitas hidup dan aktifitas fisik (Mehmet T.D., 2013).Nyeri punggung bawah pascapersalinan dapat disebabkan oleh perubahan fungsi neuromuskular pada otot area trunk dan abdominal. Latihan menjadi pilihan tepat untuk merehabilitasi fungsi otot yang dinamis dan berperan sebagai stabilisator tubuh pada pascapersalinan. Latihan penguatan dapat mengembalikan pergerakan otot area ini dan mampu mengurangi cedera mekanik yang dialami otot pada pascapersalinan untuk mengurangi keluhan nyeri punggung dan nyeri pada pelvic serta dapat mempercepat 
19 Jurnal Ilmu dan Teknologi Kesehatan, Vol 6 Nomor 1, September 2018, hlm : 15 - 24

kembalinya wanita pada aktivitas fungsionalnya (Jill 2004).

Ada beberapa metode pengukuran nyeri punggung bawah salah satunya Numerical Rating Scale (NRS) yang dilakukan dalam penelitian ini. Pada pengukuran ini menyatakan dengan bentuk numerik disertai dengan gambar yang menyatakan perasaan sesuai dengan level nyeri yang dirasakan seseorang secara spesifik memiliki interpretasi yang jelas. Berikut adalah interpretasi NRS :

0 : tidak Nyeri

\section{1-3: Nyeri Ringan}

4-6: Nyeri sedang

7-10 Sangat Nyeri

Sedangkan pengukuran Kemampuan fungsional pada nyeri punggung bawah digunakan Modified Oswetry Dissability Index (ODI). Kemampuan fungsional merupakan sesuatu yang penting dan menjadi yang utama terganggu akibat nyeri punggung bawah. Ukuran kemampuan fungsional ada beberapa metode yang dipakai untuk mengetahui kemampuan fungsional diantaranya Rolland Moris Quetionere (RMQ), Modified Oswetry Dissability Index (ODI). Penelitian ini menggunakaditunjukkan oleh penyataan nyeri punggung bawah sehingga mengganggu aktifitas fungsional. Bahwa

kemampuan fungsional selalu terkait denganm nyeri. Hasil pengukuran rendahnya kemampuan fungsional sesorang menunjukkan tingkat nyeri (Aslan 2016) Modified Oswetry Dissability Index (ODI) menyatakan level nyeri punggung bawah sesuai persentase yang ada dalam item pernyataan di setiap poi. Modified ODI menjadi pilihan dan lebih valid dinyatakan karena lebih efektif dalam menyatakan tingkat keparahan nyeri disesuaikan dengan kemampuan fungsional.

Berikut merupakan intrepretasi Modified ODI :

$0-20 \%=($ ketidaksempurnaan minimal

$21-40 \%=$ ketidakmampuan sedang

$41-60 \%=$ ketidakmampuan berat

$61-80 \%=$ Lumpuh

Trunk Balance Exercise dan Strength Training Exercise adalah dua latihan yang digabungkan menjadi satu terdiri dari aspek latihan keseimbangan otot postural yang melibatkan mobilitas pelvic dan meningkatkan aktifitas dan stabilitas otot trunk dimana terjadi peningkatan aktifitas otot segmen spinal. Latihan ini berpengaruh melalui peningkatan neural control unit dari peningkatan stabilitas system pada area spinal (Robertto 2011). Latihan penguatan segmen spinal yang mengacu pada aktivasi otot abdominal dan back yang spesifik 
terhadap latihan pada otot abdominal (upper dan oblique abdominal) dan back extensor. Aktivasi otot pada segmental tersebut yang akan mereduksi rasa nyeri pada area punggung bawah yang mengakibatkan disabilitas pada penderitanya (Bhojan 2016)

Trunk Balance Exercise menjadi latihan yang bertujuan menyeimbangkan fungsi postural pada segmen spinal yang diharapkan adanya peningkatan aktifitas pada otot terdalam sehingga terjadi perluasan kordinasi otot di area segmen spinal (Robertto 2011). Peningkatan aktifitas yang menyeluruh ini akan mereduksi nyeri sepanjang area tulang belakang (Bhojan 2016).

\section{METODE}

Jenis penelitian ini adalah termasuk ke dalam jenis pra-eksperimen dengan desain one group pre test dan post test. Pada penelitian ini akan dilakukan pemeriksaan sebelum (pre-test) dan setelah (post-test) diberikan perlakuan.

Populasi dalam penelitian ini adalah seluruh ibu pasca persalinan 12-18 bulan di Posyandu Wilayah Kelurahan Cipayung Jakarta Timur berjumlah 124 orang ibu pasca persalinan.

Peneliti menentukan sampel 13 orang sebagai kelompok intervensi dengan 10\% sebagai cadangan responden drop out yaitu 2 orang. Total sample yang mendapat intervensi berjumlah 15 orang dengan teknik pengambilan sampel yaitu sampel bertujuan atau purposive sampling. Teknik pengambilan sampel berdasarkan atas kriteria tertentu dan pertimbangan oleh peneliti. Sampel yang diambil sesuai dengan kriteria inklusi Ibu pascapersalinan dengan usia kelahiran 12-18 bulan, proses persalinan normal ataupun SC (Sectio Caesaria), usia Ibu 20-46 tahun, dengan nilai NRS minimal 3 dan ODI minimal $10 \%$, mengalami keluhan nyeri punggung bawah (di anjurkan mengalami keluhan sejak masa kehamilan), bersedia untuk menjadi responden dalam penelitian dengan persetujuan lisan dan tulisan. Kriteria eksklusi yaitu Kondisi persalinan termasuk kegawatdaruratan obsetrik dan memiliki riwayat kehamilan beresiko tinggi (missal: diabetes meitus gestasional, hipertensi, preeclampsia, dan toxemia), memiliki riwayat inflamatory arthritis, dan kondisi medis apapun yang berkaitan dengan gangguan neurologi, memiliki riwayat patologi antara lain kanker, patah tulang iga, pendarahan atau luka terbuka di area tubuh, penyakit keganasan lain atau merupakan indikasi tindakan pembedahan .

Penelitian ini dilakukan di Posyandu Wilayah Kelurahan Cipayung, Jakarta 
Timur dan waktu penelitian dimulai sejak penyusunan pada bulan Desember 2017 sampai dengan Juli 2018. Variabel dalam penelitian ini dibedakan menjadi dua, yaitu variable bebas dan variable terikat. Variabel bebas yaitu Trunk Balance Exercise dan Strength Training Exercise. variabel akibat atau variabel tidak bebas. Variabel terikat dalam penelitian ini adalah nyeri punggung bawah pasca $12 \quad-18$ bulan persalinan. Intervensi Trunk Balance Exercise dan Strength Training Exercise pada 15 orang ibu pasca 12-18 bulan persalinan Trunk Balance Exercise dan Strength Training Exercise dengan selama 4 minggu dengan dosis frekuensi 3 kali seminggu 10-12 repetisi 3 set durasi latihan selama $45-60$ menit. Analisis yang dilakukan terhadap variabel pascapersalinan, Trunk Balance Exercise dan Strength Training Exercise, nyeri punggung bawah berkaitan dengan kemampuan fungsional dari hasil pengukuran NRS dan Modified Oswtery Disability Index. Hasil analisis data berupa mean, minimal, maksimal dan standar deviasi untuk mendapatkan gambaran tiap variabel yang diteliti dan disajikan alam bentuk tabel distribusi frekensi atau diagram. Pada analisis bivariat dianalisis hubungan antar variabel dependen dan independen dengan menggunakan pengujian statistik. Analisis bivariat dilakukan untuk melihat hubungan antara pemberian Trunk Balance Exercise dan Strength Training Exercise dengan tingkat nyeri punggung bawah pasca 12-18 bulan persalinan berupa pengukuran dengan NRS. Uji normalitas data dilakukan dengan membagi nilai skewness dan standard error. Setelah dilakukan uji normalitas data yang diketahui berdistribusi normal maka uji hipotesis menggunakan uji parametrik yakni Paired Sample T-Test. Uji parametrik ini digunakan untuk mengetahui adanya pengaruh pemberian intervensi. Etika penelitian yang harus diperhatikan oleh peneliti yaitu responden yang berpastisipasi dalam penelitian atas dasar sukarela dan tanpa paksaan, menjaga kerahasiaan penelitian. Hal ini dapat dilakukan dengan anonimity (tanpa nama), menjaga agar penelitian yang dilakukan tidak merugikan responden dalam segi apapun, melaksanakan penelitian secara baik dan benar sesuai dengan kaidah ilmiah dan standar operasional prosedur, menghindari plagiarisme, pemalsuan, dan misconduct dalam pelaksanaan penelitian, Dilaksanakan pengajuan telaah etik penelitian ke tim review etik penelitian di wilayah Kecamatan Cipayung. Penelitian ini telah mendapat persetujuan etik dari Komisi Etik Poltekkes Kemenkes Jakarta III (KEPK-PKKJ3) dengan No.KEPK-PKKJ3/102/III/2018. 


\section{HASIL DAN PEMBAHASAN}

Pada penelitian ini setelah responden melakukan latihan Trunk Balance dan Strength Training Exercise untuk mengurangi tingkat nyeri punggung bawah dan peningkatan selama 4 minggu atau 12 kali latihan. Sebelum intervensi ditemukan rata-rata NRS responden 5,00 (nyeri sedang) dan sesudah intervensi diberikan rata-rata NRS responden menjadi 2,00 (nyeri ringan). Dari pengukuran tersebut menunjukkan hasil $p$ value $0,000<\alpha$ yang berarti hasil penelitian ini signifikan sehingga hal ini menunjukkan terdapat pengaruh Trunk Balance Exercise dan Strength Training Exercise terhadap nyeri punggung bawah pasca 12-18 bulan persalinan: studi di Posyandu Wilayah Kelurahan Cipayung Jakarta Timur Tahun 2018 .

Dari penelitian yang dilakukan, penelitian ini sedikit berbeda dengan penelitian sebelumnya yang dilakukan oleh Bhojan Kannabiran, et al yang berjudul "Trunk Balance Exercise and Strength Training Exercise in the Management of Pain and Disability Among the Chronic Low Back Pain Individuals" di India tahun 2016. Pada penelitian Bhojan Kannabiran,et al alat ukur yang digunakan untuk mengetahui tingkat nyeri punggung bawah menggunakan Visual Analog Scale (VAS) pada individu dengan nyeri punggung bawah kronik. Sedangkan pada penelitian ini digunakan alat ukur NRS untuk mengukur nyeri punggung bawah. Namun, untuk hasil pada kedua penelitian ini terjadi penurunan tingkat nyeri punggung bawah dan peningkatan kemampuan fungsional yang ditunjukkan dengan p-value sebesar 0,05 pada penelitian Bhojan Kannabiran,et al. Sedangkan, pada penelitian ini p-value sebesar 0,00. Hal ini menyatakan bahwa adanya perbedaanya alat ukur maka nilai $p$ value juga berbeda. Dengan nilai signifikansi lebih signifikan pada penelitian ini dibandingkan penelitian Bhojan Kannabiran, et al tahun 2016.

Walaupun hasil yang diperoleh sama-sama signifikan namun, penelitian ini dengan penelitian sebelumnya yang dilakukan oleh Bhojan Kannabiran memiliki perbedaan lainnya yaitu dari segi waktu latihan yang diberikan, dimana pada penelitian sebelumnya waktu latihan Trunk Balance Exercise dan Strength Training Exercise yaitu selama 12 minggu dengan intensitas 3 kali seminggu durasi latihan 45-60 menit atau sebanyak sedangkan, pada penelitian ini latihan hanya dilakukan selama 4 minggu dengan intensitas 3 kali seminggu atau sebanyak 12 kali latihan. Dilihat dari data tersebut dapat dikatakan bahwa penelitian ini lebih signifikan dalam 
menurunkan tingkat nyeri punggung bawah dan kemampuan fungsional pasca 12-18 bulan persalinan dibandingkan dengan penelitian sebelumnya oleh (Bhojan 2016).

Trunk Balance dan Strength Training Exercise dapat berpengaruh terhadap penurunan tingkat nyeri punggung bawah pasca 12-18 bulan persalinan menurut Bhojan Kannabiran, 2016 terdapatnya aktivitas otot dengan level dan dosisi tinggi dapat meningkatkan kinerja atau kontraksi otot hingga pada deep muscle pada segmen spinal sehingga terdapatnya perluasan kordinasi aktivasi otot yang dapat mereduksi nyeri. Hal ini sejalan dengan pendapat Nikolaos Kofotolis, 2016 bahwa adanya latihan penguatan pada area abdominal dan trunk dapat meningkatkan kekuatan oto pada asegmen tersebut kemudian terjadi keseimbangan postural dan sensasi nyeri punggung dapat berkurang akibat adanya kinerja otot yang seimbang. Penurunan tingkat nyeri punggung bawah ini juga ditunjukkan melalui hasil dari penelitian ini yang mendukung bahwa latihan inin memang memiliki pengaruh terhadap tingkat nyeri punggung bawah.

\section{SIMPULAN}

Hasil penelitian dan pembahasan tentang Pengaruh Trunk Balance Exercise dan Strength Training Exercise pada nyeri punggung bawah pasca 12-18 Bulan Persalinan: Studi di Posyandu Wilayah Kelurahan Cipayung Jakarta Timur dapat disimpulkan Nyeri punggung bawah pada ibu pasca 12-18 bulan persalinan sebelum dilakukan intervensi Trunk Balance dan Strength Training Exercise menunjukkan rerata nilai NRS sebesar 5,00 dan ODI. Nyeri punggung bawah pasca 12-18 bulan persalinan sesudah dilakukan intervensi Trunk Balance dan Strength Training Exercise menunjukkan rerata nilai NRS sebesar 2,00. Terdapat pengaruh pemberian Trunk Balance Exercise dan Strength Training Exercise terhadap penurunan tingkat nyeri punggung bdawah pasca 12-18 bulan persalinan di Posyandu Wilayah Kelurahan Cipayung Jakarta Timur ditunjukkan oleh hasil selisih rerata NRS sebesar $-3,00$ pada penelitian ini. Sehingga dinyatakan signifikan berpengaruh sesuai dengan $p$ value $0,000<\alpha$. Keberhasilan ini ditentukan dari faktor pemilihan gerakan yang sesuai, kondisi kesehatan responden, serta sesi latihan dan dosis latihan yang benar.

\section{DAFTAR RUJUKAN}

Anderson, G. dan O, H. 1992. Postpartum Low Back Pain. Spine. 17(1). hal. 53-55.

Aslan, B. 2016. Cross-Cultural Adaptation, Validation, and Reliability Testing of the Modified Oswestry Disability 
Questionnaire in Persian Population with Low Back Pain. Asian Spine Journal, April. 1(2).

Bahadoran, P. 2007. Evaluating the Effect of Exercise on the Postpartum Quality of Pain.

Bastiaenen, C. dan D, B. 2008. Long-term effectiveness and costs of a brief self-management intervention in women with pregnancy-related low back pain after delivery. $B M C$ Pregnancy Childbirth. 19.

Bhojan, K. 2016. Trunk Balance Exercises and Strength Training Exercises in the Management of Pain and Disability Among the Chronic Low Back Pain. Journal of Spine. 5(1-8).

Irion, J. M. dan Irion, G. 2010. Women's health in physical therapy. Wolters Kluwer.
Jill, M. 2004. Physiotherapy in Obsetrics Gynaecology. Elsivier Science.

Lilis, L. S. 2013. Asuhan Kebidanan Terkini Kegawat Daruratan Maternal dan Neonatal. Jakarta: CV.Trans Info Media.

Morgen, I. 2008. Physical activity and persistent low back pain and pelvic. BMC Public Health. 8. hal. 417.

P, K. 2011. Pregnancy-Related Low Back Pain.

Robertto. 2011. Efficacy of Trunk Balance Exercises for Individuals With Chronic Low Back Pain. Journal of Orthopaedics and Sport Physical Therapy,. 41(8). hal. 452-455. 